\title{
Optimising water requirement for nursery rearing of rohu Labeo rohita (Hamilton, 1822) in large outdoor concrete tanks: influence of water depth on seed performance
}

\author{
PRATAP CHANDRA DAS AND SUHAS PRAKASH KAMBLE* \\ ${ }^{I}$ ICAR-Central Institute of Freshwater Aquaculture, Kausalyaganga, Bhubaneswar - 751 002, Odisha, India \\ ${ }^{2}$ ICAR-Central Inland Fisheries Research Insitute, Barrackpore - 700 120, Kolkata, West Bengal, India \\ e-mail: pratapcdas@yahoo.com
}

\begin{abstract}
A study was conducted to find the optimum water depth requirement for nursery rearing of rohu Labeo rohita (Hamilton, 1822). Nine concrete tanks of $50 \mathrm{~m}^{2}$ each $(10 \times 5 \times 1.2 \mathrm{~m})$ were grouped into three treatments $\mathrm{T} 1, \mathrm{~T} 2$ and $\mathrm{T} 3$ and were filled upto $1.0,0.75$ and $0.5 \mathrm{~m}$ water depths, respectively. Each tank was stocked with 0.5 lakh hatchery produced spawn and reared for 20 days. The study revealed significant influence of water depth on growth and survival of fry $(\mathrm{p}<0.05)$. Though the final length of fry did not differ among the treatments ( $>0.05$ ), T3 with $0.5 \mathrm{~m}$ water depth showed significantly lower survival, final body weight and specific growth rate than the other two treatments $(\mathrm{p}<0.05)$, whereas tanks with 1.0 and $0.75 \mathrm{~m}$ water depths showed almost similar survival, final weight and SGR ( $>0.05)$. Assessment of water use for production of every 1000 fry revealed significant reduction in total water use (TWU) with decreased water depth $(\mathrm{p}<0.05)$, while the consumptive water use (CWU) in terms of water exchange and replenishment did not differ between water depth treatments of 1.0 and $0.75 \mathrm{~m}$. The results of the study indicate $0.75 \mathrm{~m}$ to be the ideal water depth with better water use efficiency for fry production of the species.
\end{abstract}

Keywords: Growth, Nursery rearing, Rohu, Survival, Water use efficiency

Obtaining freshwater from natural sources for fish farming is becoming increasingly difficult in India. The per capita water availability per year in India has been declining year after year from $5178 \mathrm{~m}^{3}$ in 1951 through 2210, 1829 and $1544 \mathrm{~m}^{3}$ in 1991, 2001 and 2011, respectively and is estimated to be $1421 \mathrm{~m}^{3}$ by 2021 (CSO, 2018). Since the country has already reached a 'water stressed' situation as per international norms (India-WRIS, 2019), judicious use of the available natural resources is of paramount importance, particularly so for freshwater fish farming, as the water requirement for this activity is usually high. In recent years, efforts have been directed towards devising novel methods and modifying the existing practices in fish farming to increase water use efficiency. Augmentation of the natural productivity of pond through fertilisation, optimum stocking density and supplementary feeding are the three major factors that determine the success of carp seed rearing. Working on the several recommended fertilisation schedules followed for preparation of carp nursery, Jena and Das (2011) have recommended phased fertilisation $(750 \mathrm{~kg}$ groundnut oil cake, $200 \mathrm{~kg}$ cowdung and $50 \mathrm{~kg}$ single super phosphate, applied in three splits, one before and two after spawn stocking) for maintaining sustained plankton production and better fry performance in the 15-20 days nursery phase of Indian major carps (IMC). The usual daily ration of supplementary feed is provided at approximately $400 \%$ of initial spawn biomass ( $6 \mathrm{~kg}$ per million spawn) on day 1 and subsequently doubled and tripled on day 6 and day 11, respectively (Jena and Das, 2011). However, Das et al. (2015) observed similar growth performance for fry fed at 75 and $100 \%$ of the above mentioned ration and recommended the former, thereby saving good amount of supplementary feed. Similar attempts have also been made over the years to modify use of various other inputs to refine the carp seed production technology (Jena et al., 1998; Das et al., 2015; Kamble et al., 2017).

Apart from fertilisation and supplementary feeding, depth of water in nursery also plays a significant role on the growth performance of the fry. While earthen ponds are generally used for carp nursery, constraints in availability of pond area for seed production has led many farmers in recent years to resort to high density seed rearing in large concrete tanks. With recommended levels of 1.0-1.5 m water depth (Das and Sinha, 1985; Carlos and Santiago, 1988; Jena and Das, 2011), filling up to the required depth and its maintenance against seepage and evaporation loss in such systems form a major investment. However, studies have seldom focused on the influence of water depth on fry performance and so, possible wastage of water in these systems might have been overlooked. 
In view of impending water scarcity, optimising the water depth requirement in the nursery systems might be a good proposition to save water and thereby increase the water productivity and economic efficiency of the seed production system. The present study is an attempt in this direction.

The study was carried out in a set of nine large concrete tanks $(10 \times 5 \times 1 \mathrm{~m})$ in the seed rearing complex of ICAR-Central Institute of Freshwater Aquaculture (ICAR-CIFA), Bhubaneswar, India. The tanks were grouped into three treatments T1, T2 and T3 and were filled with filtered pond water upto $1.0 \mathrm{~m}, 0.75 \mathrm{~m}$ and $0.50 \mathrm{~m}$, respectively, 5 days before stocking the spawn. Liming with $\mathrm{CaCO}_{3}$ at $1 \mathrm{~kg}$ per tank $\left(200 \mathrm{~kg} \mathrm{ha}^{-1}\right)$ was carried out after filling water followed by fertilisation on the next day using phased fertilisation schedule as suggested by Jena et al. (2009). The first split dose was applied three days before stocking the spawn, while the second and third were applied on the $6^{\text {th }}$ and $11^{\text {th }}$ day respectively (Das et al., 2015). Groundnut oilcake, soaked overnight and mixed with cow dung and SSP (single super phosphate) was made into a thick paste and then to a slurry and applied uniformly in the tanks. Each tank was stocked with 50,000 spawn of rohu Labeo rohita (Hamilton, 1822), produced in the hatchery of the Institute, after due acclimatisation. The spawn samples, collected at random, were measured for average initial length and weight, which were estimated as $7 \mathrm{~mm}$ and $1.6 \mathrm{mg}$, respectively. Powdered mixture of groundnut oil cake (crude protein $43 \%$ ) and rice bran (crude protein 11\%) were mixed at equal proportions by weight and was used for supplementary feeding during the nursery phase. Daily ration started with $450 \mathrm{~g}$ per lakh spawn (approximately $300 \%$ of the initial spawn biomass) on the first day (Das et al., 2015) and increased by $75 \mathrm{~g}$ per lakh spawn on each subsequent day. The daily ration, divided in two splits, was broadcasted twice during 07:00 - $0800 \mathrm{hrs}$ and 16:00 - 21:00 hrs. No water exchange was carried out during the study period. However, the water loss due to evaporation was compensated in the tanks once every 5 days.

Water samples from the tanks were collected during 08:00 - 09:00 hrs at 5 day intervals for measurement of important parameters viz., temperature, $\mathrm{pH}$, dissolved oxygen (DO), total alkalinity, total hardness and dissolved inorganic nutrients including total ammonia-nitrogen (TAN), nitrite and nitrate. While temperature, $\mathrm{pH}$ and transparency were measured in situ, the other parameters were analysed in the laboratory following standard methods (APHA, 2005).

Plankton samples were collected by filtering 501 of water from each tank through bolting silk net (No. 25, mesh size $64 \mu$ ) and were preserved in $4 \%$ formaldehyde solution for quantitative analysis. Samples were analysed for phyto- and zoo-plankton count by direct census method (Jhingran et al., 1969) using Sedgwick-Rafter counting cell under a binocular microscope (Olympus BX 51).

Although the growing larvae in each tank were examined periodically for feed intake and presence of any abnormality such as bulging abdomen, parasites or lesions, interim sampling for length and weight measurements was not done to avoid mortality during handling. However, the same were measured in detail during the final harvest which was done on $20^{\text {th }}$ day by repeated netting followed by complete draining of the tank. In each tank, fry measured in five cups were counted individually to determine the average number per cup and accordingly, total number of fry harvested was determined. Mean weight of fry was recorded by taking the average of three random samples of 50 fry each from each tank, while individual length of 25 fry were taken from each tank to determine the mean total length.

The data were subjected to statistical analysis using SPSS v.16. One-way analysis of variance was used to compare all the treatments. Duncan's multiple range test was performed at $95 \%$ significance level to compare the treatment means for different parameters.

The water quality parameters recorded in the experimental tanks during the study period are presented in Fig. 1 and 2. Water temperature ranged between $30-31.5^{\circ} \mathrm{C}$. Although variation in the different water quality parameters were observed in the treatments with regard to days of rearing, no marked influence of varied water depth on water quality was observed among the treatments, except in T2 in which higher DO and lower transparency were discernible. An increase in water $\mathrm{pH}$ was observed in the treatments during the initial five days, but this subsequently stabilised between 8.0 and 8.3 till the end of the study (Fig. 1). Unlike pH, the dissolved oxygen content increased in all treatments during the initial half phase (upto $10^{\text {th }}$ day), while it reduced during the latter half of the study (11-20 days). Both total alkalinity and hardness remained almost unchanged during first half phase of the study, but slightly decreased in the later phase. An increase in plankton density (both phyto- and zoo-plankton) and a corresponding decrease in the transparency were observed in the tanks during the first phase, which almost stabilised in the later phase.

A marked increase in the TAN content of water was observed in the treatments from $6^{\text {th }}$ to $11^{\text {th }}$ day, but in the later phase it increased at slower rate (Fig. 2). Both nitrite and nitrate levels, after a brief increase in the first week, came down to a lower level. 

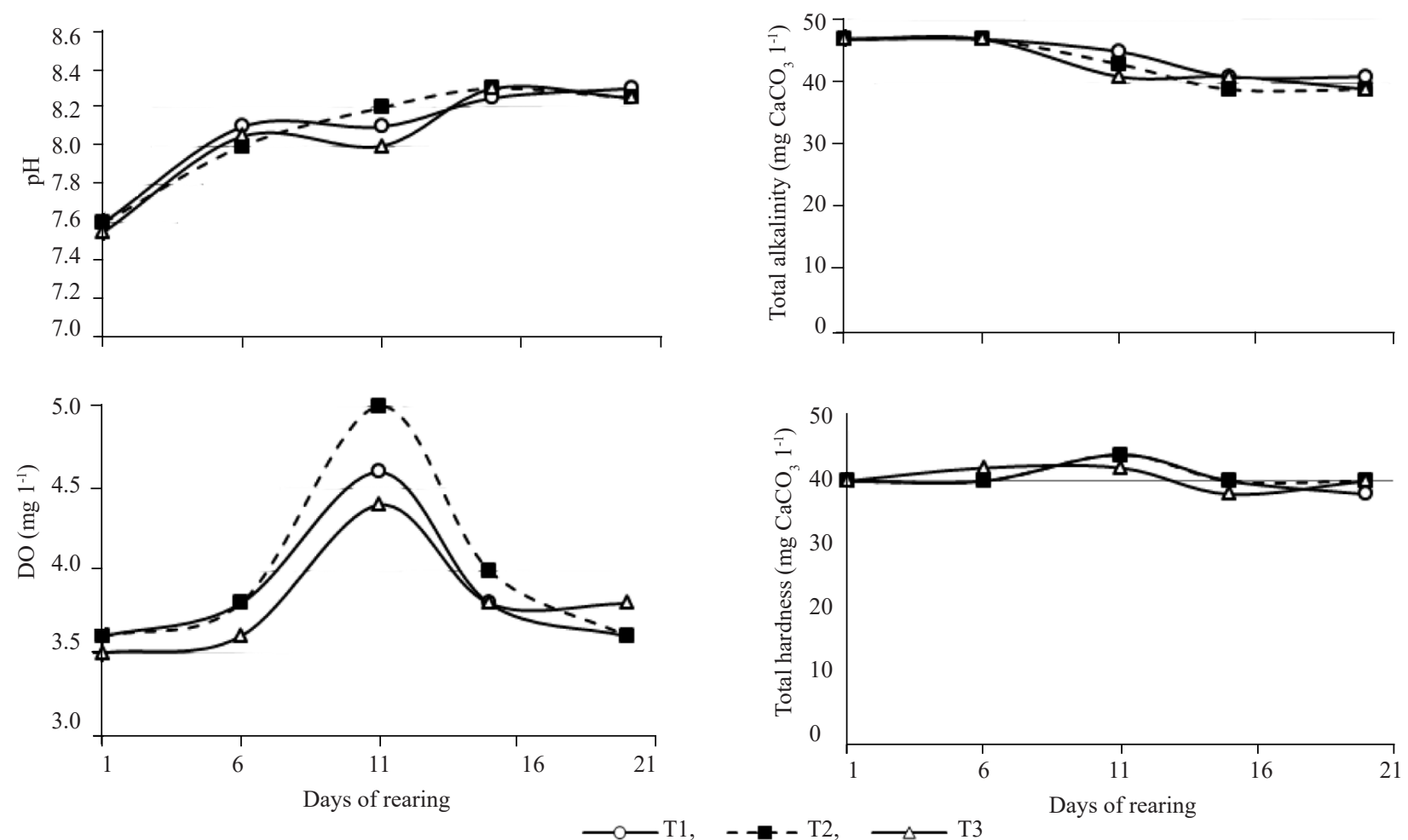

Fig.1. Water quality parameters recorded during the nursery rearing of rohu, at varied water depths $(n=3)$

Fry survival was significantly lower $(\mathrm{p}<0.05)$ with $0.5 \mathrm{~m}$ water depth in T3 while that in 0.75 and $1.0 \mathrm{~m}$ depth tanks were similar $(\mathrm{p}>0.05)$ (Table 1$)$. The harvested body weight and specific growth rate were also significantly lower $(\mathrm{p}<0.05)$ in T3 than in the other two treatments. The total water use (TWU) among the treatments reduced from T1 to T3 (Table 1), obviously due to use of reduced water depth. But, the consumptive water use (CWU) for fry production (1000 fry) remained significantly higher in T3 $(p<0.05)$, while it was almost similar in the other two treatments $(\mathrm{p}>0.05)$.

The initial increase in water $\mathrm{pH}$ observed in the tanks could be attributed to the application of lime during pre-stocking. Liming also might have raised the initial alkalinity level as observed in the tanks (Fig. 1), whereas subsequent reduction towards the original level (38-40 mg as $\mathrm{CaCO}_{3} \mathrm{1}^{-1}$ ) was obviously due to reduced effectiveness of lime (Fig. 1). The reduction in transparency and corresponding increase in phytoplankton density during the initial 10 days (Fig. 2) indicated greater photosynthetic activity in tank water. The increasing DO level in this phase (Fig. 1) also indicated high photosynthetic activity which might have helped in stabilising the $\mathrm{pH}$ in all the treatments in later phase despite reduction in alkalinity. But there was no marked change in the plankton density in later half phase (11-20 days). Although the third dose

Table 1. Yield attributes and water requirement (Mean $\pm \mathrm{SD}, \mathrm{n}=3$ ) during nursery rearing of rohu fry in large concrete tanks

\begin{tabular}{llll}
\hline Treatments (Water depth) & T-1 $(1.00 \mathrm{~m})$ & T-2 $(0.75 \mathrm{~m})$ & T-3 $(0.50 \mathrm{~m})$ \\
\hline Total length $(\mathrm{cm})$ & $2.43 \pm 0.14^{\mathrm{a}}$ & $2.42 \pm 0.014^{\mathrm{a}}$ & $2.24 \pm 0.09^{\mathrm{a}}$ \\
Harvest weight $(\mathrm{g})$ & $0.21 \pm 0.03^{\mathrm{a}}$ & $0.18 \pm 0.02^{\mathrm{a}}$ & $0.14 \pm 0.01^{\mathrm{b}}$ \\
\% Weight gain & $12971 \pm 1810^{\mathrm{a}}$ & $11049 \pm 137^{\mathrm{a}}$ & $8336 \pm 412^{\mathrm{b}}$ \\
Specific growth rate $\left(\mathrm{SGR} \%\right.$ day $\left.^{-1}\right)$ & $24.33 \pm 0.69^{\mathrm{a}}$ & $23.57 \pm 0.39^{\mathrm{a}}$ & $22.17 \pm 0.24^{\mathrm{b}}$ \\
Survival $(\%)$ & $53.32 \pm 3.76^{\mathrm{a}}$ & $47.40 \pm 2.98^{\mathrm{ab}}$ & $44.97 \pm 3.39^{\mathrm{b}}$ \\
Total water use (TWU) $\left(\mathrm{m}^{3}\right)$ & $58.5 \pm 2.5$ & $45.5 \pm 1.0$ & $33.6 \pm 0.6$ \\
Consumptive water use $(\mathrm{CWU})\left(\mathrm{m}^{3}\right)$ & $13.5 \pm 3.0$ & $13.6 \pm 2.4$ & $15.3 \pm 1.0$ \\
TWU for 1000 fry $\left(\mathrm{m}^{3}\right)$ & $2.20 \pm 0.18^{\mathrm{a}}$ & $1.93 \pm 0.14^{\mathrm{b}}$ & $1.50 \pm 0.10^{\mathrm{c}}$ \\
CWU for 1000 fry $\left(\mathrm{m}^{3}\right)$ & $0.51 \pm 0.13^{\mathrm{b}}$ & $0.58 \pm 0.13^{\mathrm{b}}$ & $0.68 \pm 0.08^{\mathrm{a}}$
\end{tabular}

Values with different superscripts in a row differ significantly $(\mathrm{p}<0.05$ ) 

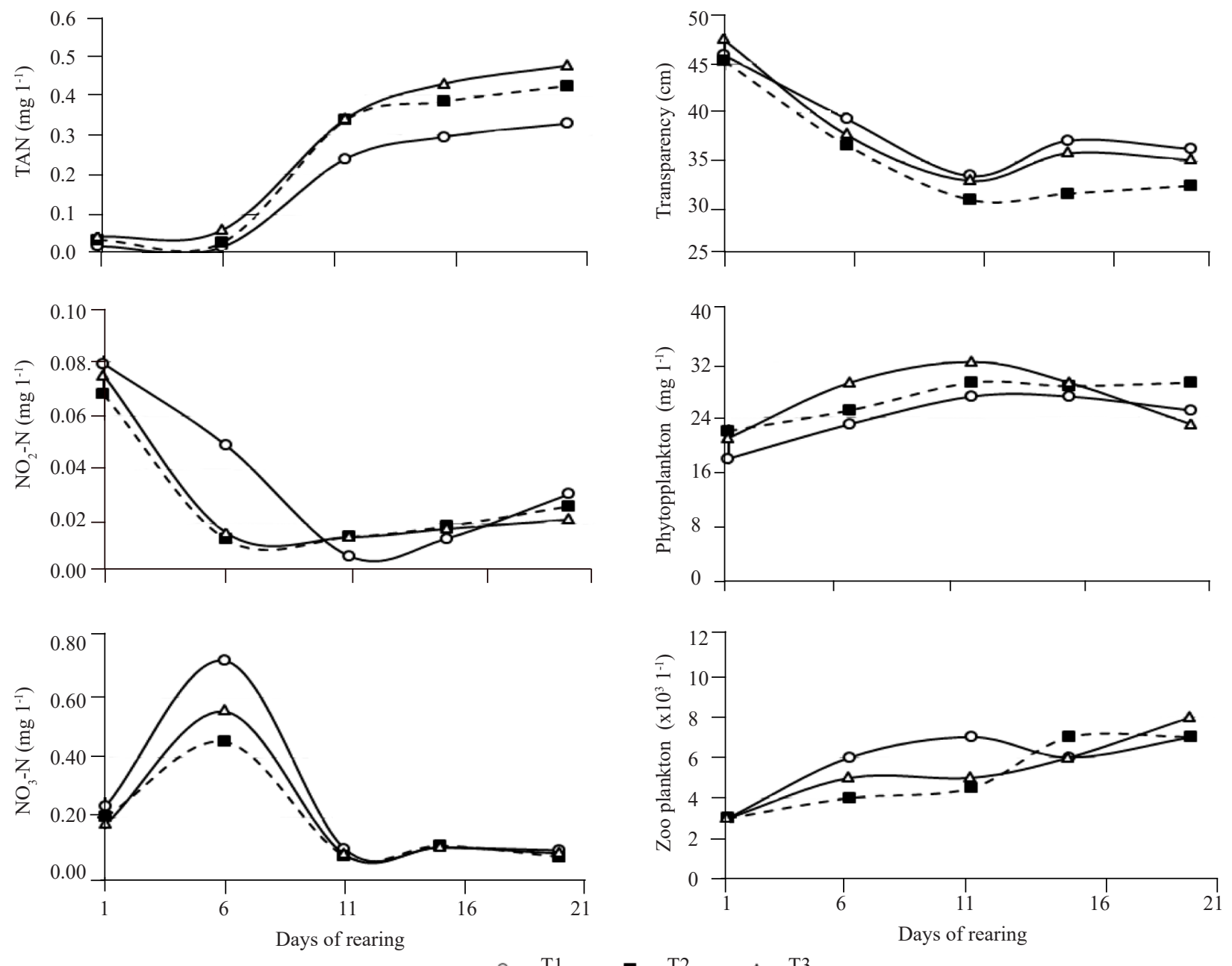

Fig. 2. Inorganic nutrients and plankton density recorded in tanks during nursery rearing of rohu, at varied water depths $(n=3)$

of phased fertilisation on $11^{\text {th }}$ day would have helped boosting the phytoplankton population, as evident from an increase in zooplankton during this phase, the increasing plankton intake capacity of the growing fry might have limited plankton density and growth. As a result, reduced photosynthetic activity coupled with greater respiratory demand of the increasing fry biomass might have caused the observed reduction of DO content in the later phase.

Prevalence of higher DO level in tanks during the second week would have facilitated mineralisation process (Ghosh and Mohanty, 1981; Boyd 1990; Mohanty et al., 1994; Das et al., 2005), thereby contributing towards the observed rise in the TAN levels as a result of decomposition of the accumulating wastes (Hargreaves and Tucker, 2004). Such higher DO level also might have led to faster conversion of ammonia through nitrite and nitrate phases facilitating nitrogen availability to the phytoplankton, whose density was also higher during this phase causing a higher uptake. In the second phase however, continued mineralisation of the accumulated wastes contributed to maintain the TAN at higher levels in all the treatments, while it also led to reduction of DO levels in water (Avnimelech and Ritvo, 2003; Hargreaves and Tucker, 2004; Jimenez-Montealegre et al., 2005). The DO values nearer to $3.5 \mathrm{mg} \mathrm{l}^{-1}$ probably did not support the ammonia oxidation process, resulting in lower nitrite and nitrate levels in all the treatments in the subsequent phase. Nevertheless, all the water quality parameters prevailed in the tanks were within the values reported earlier in nursery tanks systems of carps (Basavaraja and Antony, 1997; Jena et al., 1998; Jahan et al., 2013; Das et al., 2016).

With regard to influence of water depth on water quality, the highest peak of dissolved oxygen on $11^{\text {th }}$ day and a lower water transparency in most part of the study in T2 indicated prevalence of higher planktonic mass. The higher phytoplankton density in T2 than that of 
T1 (Fig. 1), despite their statistically similar fry survivals (Table 1), could be attributed to the lower water depth in the former $(0.75 \mathrm{~m})$ that favoured more plankton growth than in T1 with $1 \mathrm{~m}$ water depth. Also the marginally lower fry survival $(6 \%)$ in T2 might have caused less plankton utilisation by fry, thereby increasing the plankton density in the last part of the study. Similar schedule and quantity of supplementary feeding were provided in all the treatments during the study. But the TAN content relatively varied in the order $\mathrm{T} 1<\mathrm{T} 2<\mathrm{T} 3$, which could be attributed to more dilution in the presence of higher water mass in the respective treatments.

Varied water depth showed significant influence on the fry growth and survival in the study. Significantly lower fry survival, harvested body weight and SGR $(p<0.05)$ in T3 indicated poor yield performance of fry despite its higher consumptive water requirement (CWU), thereby suggesting the water depth of $0.5 \mathrm{~m}$ (T3) to be unsuitable for carp fry rearing. Whereas T1 and T2, despite having varied water depth, showed similar yield attributes (total length, harvest weight, $\%$ weight gain and SGR) except for $6 \%$ higher survival in the former. But this $6 \%$ higher survival (additional yield of 60 fry $\mathrm{m}^{-3}$ ) in T1 was achieved at the cost of $0.25 \mathrm{~m}$ additional water depth compared to $\mathrm{T} 2$, which can be compromised in situation of water scarcity. Moreover, study on water use for production of every 1000 fry (Table 1) in these two treatments revealed similar CWU $(\mathrm{p}>0.05)$, but the TWU was significantly lower in $\mathrm{T} 2(\mathrm{p}<0.05)$. Thus the present study recommends a water depth of $0.75 \mathrm{~m}$ in carp nursery for more productive use of water.

\section{Acknowledgements}

The authors are grateful to the Director, ICARCIFA, Bhubaneswar for facilities provided. The study was conducted as an activity under the CRP-Water Project with financial assistance from 'Consortia Research Platform on Water' of ICAR which is duly acknowledged. The authors also acknowledge the support of the Director of the Nodal Institute-ICAR-Indian Institute of Water Management, Bhubaneswar.

\section{References}

APHA 2005. Standard methods for the examination of water and wastewater, $21^{\text {st }}$ edn. American Public Health Association, Washington, DC, USA.

Avnimelech, Y. and Ritvo, G. 2003. Shrimp and fish pond soils: processes and management. Aquaculture, 220: 549-567. doi.org/10.1016/S0044-8486(02)00641-5.

Basavaraja, N. and Antony, J. M. 1997. Rearing of spawn and fry of Cyprinus carpio on conventional and supplementary feed. Indian J. Fish., 44(2): 165-170.
Boyd, C. E. 1990. Water quality in ponds for aquaculture Auburn University Agricultural Experiment Station, Auburn, AL, USA, 482 pp.

Carlos, M. H. and Santiago, C. B. 1988. Nursery and grow-out operation for tilapia and carp. In: Juario J. V. and Benitez, L. V. (Eds.), Perspectives in aquaculture development in South-east Asia and Japan: Contributions of the SEAFDEC Aquaculture Department. Proceedings of the Seminar on Aquaculture Development in South-east Asia, 8-12 September 1987, South-east Asian Fisheries Development Centre, Tigbauan, Iloilo, Philippines, p. 281-292.

CSO 2018. EnviStats-India 2018: Supplement on environmental accounts. Central Statistics Office, Ministry of Statistics and Programme Implementation, Government of India, New Delhi, 249 pp.

Das, P. and Sinha, M. 1985. Carp seed raising: Package of practices for increasing production. Aquaculture extension manual, New Series No. 1, ICAR-Central Inland Fisheires Research Institute, Barrackpore, India, 28 pp.

Das, P. C., Ayyappan, S. and Jena, J. K. 2005. Comparative changes in water quality and role of pond soil after application of different levels of organic and inorganic inputs. Aquac. Res., 36: 785-798. doi.org/10.1111/j.13652109.2005.01288.x

Das, P. C., Jena, J. K., Patro, B. and Mohanta, D. 2015. High density rearing of rohu Labeo rohita (Hamilton) from spawn to fry in concrete tanks: effect of daily feed ration and soil base on fry growth and survival. Aquac. Res., 47: 3973-3979. DOI: 10.1111/are.12847.

Das, P. C., Jena, J. K., Patro, B. and Mishra, S. S. 2016. Growth performance of olive barb Puntius sarana (Hamilton, 1822) in response to use of different supplementary feeds during high density rearing of spawn to fry stage. Indian J. Fish., 63(1): 120-124. DOI: http://dx.doi. org/10.21077/ ijf.2016.63.1.48661-18.

Ghosh, S. R. and Mohanty, A. N. 1981. Observations on the effect of mineralization of organic nitrogen in fish pond soil. Isr. J. Aquac. Bamidgeh, 33: 50-56.

Hargreaves, J. A. and Tucker, C. S. 2004. Managing ammonia in fish ponds. Publication No. 4603. Southern Regional Aquaculture Centre, United States Department of Agriculture, USA.

India-WRIS 2019. India's water wealth. Water Resources information System of India. http://www.india-wris.nrsc. gov.in/wrpinfo/index.php? title=India \%27s Water Wealth. (Accessed 15 March 2019).

Jahan, D. A., Hussain, L., Islam, M. A. and Naima, A. 2013. Evaluation of soybean meal as a dietary protein source on the performance of Labeo rohita (Ham.) spawn reared under pond condition. The Agriculturists, 11(2): 14-20. DOI:http://dx.doi.org/ 10.3329/agric.v11i2.17482.

Jena, J. K., Das, P. C., Das, B. K., Mohapatra, B. C., Sarangi, N., Modayil, M. J., Vass, K. K., Ravichandran, P., Ponniah,A. G., Syda Rao, G., Eknath, A. E. and Ayyappan, S. 2009. 
Aquaculture technologies for farmers. Revised edn. Indian Council of Agricultur Research, New Delhi, India, 126 pp.

Jena, J. K. and Das, P. C. 2011. Carp culture. In: Verma, S. A., Kumar, A. T., Rahman, O. and Pradhan, S. (Eds), Hand book of fisheries and aquaculture, $2^{\text {nd }}$ edn. Directorate of Knowledge Management in Agriculture (DKMA), Indian Council of Agricultural Research, New Delhi, India. p. $380-400$.

Jena, J. K., Aravindakshan, P. K. and Singh, W. J. 1998. Nursery rearing of Indian major carp fry under different stocking densities. Indian J. Fish., 45(2): 163-168.

Jhingran, V. G., Natarajan, A. V., Banerjee, S. M. and Davidm, A. 1969. Methodology on reservoir fisheries investigation in India, Bulletin No. 12. ICAR-Central Inland Fisheries Research Institute, Barrackpore, India, 109 pp.
Jimenez-Montealegre, R., Verdegem, M. C. J., Van Dam, A. A. and Verreth, J. A. 2005. Effect of organic nitrogen and carbon mineralization on sediment organic matter accumulation in fish ponds, Aquac. Res., 36(10): 1001-1014. DOI: 10.1111/j.1365-2109.2005.01307.x.

Kamble, S. P., Das, P. C., Parida, K. C. and Mohanta, K. N. 2017. Effect of dietary incorporation of fish/prawn meal on performance of Catla catla (Hamilton) during nursery phase. Indian J. Fish., 64(1): 44-48. DOI: 10.21077/ijf. 2017.64.1.60074-07.

Mohanty, A. N., Chatterjee, D. K., Saha, P. K. and Pani, K. C. 1994. Effect of varying $\mathrm{C} / \mathrm{N}$ ratios on the mineralisation of organic nitrogen in fish pond soils. J. Aquac. Trop., 9: 9-14. 